\title{
AN EVALUATION OF HEAT INPUT AND EFFICIENCY TEST METHOD BASED ON SNI 7368:2011 - SINGLE BURNER LPG GAS STOVE WITH IGNITER SYSTEM
}

\section{Evaluasi Metode Pengujian Asupan Panas dan Efisiensi SNI 7368:2011 - Kompor Gas Bahan Bakar LPG Satu Tungku dengan Sistem Pemantik}

\author{
Bayu Utomo, Nanang Kusnandar, Qudsiyyatul Lailiyah, and Winda Sari Ramadhani \\ Research Center for Testing Technology, Indonesian Institute of Sciences \\ Kawasan Puspiptek Gedung 417, Tangerang Selatan 15314 \\ e-mail:bayu.utomo@lipi.go.id
}

Diterima: 19 Maret 2019, Direvisi:11 Oktober 2019, Disetujui: 6 November 2019

\begin{abstract}
Heat input and efficiency test are one of the essential aspects that should be assessed in order to meas ure the energy performance of LPG gas stove. In order to do this, the method employed to assess these performance aspects should meet the requirement of the energy test procedure. This paper presents the evaluation of energy performance test method of SNI 7368:2011 - a standard for single gas stove LPG in order to meet energy test procedure criteria. The method of evaluation is conducted through interpersonal comparative testaccording to BS EN ISO/IEC 17043:2010 - Conformity assessment - General requirements for proficiency testing. Two parameters of z-score and z-robust are used as criteria for the assessment of method evaluation. The result shows that both z-score and z-robust give the same result at satisfactoryperformance for heat input aspect, while the different performance criteria emerge in the efficiency aspect. The z-score of efficiency aspect gives satisfactory performance, whereas a questionable performance is yielded by z-robust. The further analys is of $z$ robust brings to the concern about inconsistency relation result between temperature rise, consumption of gas and the test duration. The lack of a method for ensuring the composition of gas during the test in the SNI is identified as a factor that may lead to such an inconsistent result.
\end{abstract}

Keywords: efficiency, energy test, heat input, performance, single burner gas stove

\begin{abstract}
Abstrak
Pengajuan asupan panas dan efisiensi adalah salah satu aspek penting yang harus dinilai untuk mengukur kinerja energi kompor gas LPG. Untuk melakukan ini, metode yang digunakan untuk menilai aspek kinerja ini harus memenuhi persyaratan proseduruji energi. Makalah ini menyajikan evaluasi metode uji kinerja energi SNI 7368: 2011 - standar untuk LPG kompor gas tunggal untuk memenuhi kriteria prosedur uji energi. Metode evaluasi dilakukan melalui uji komparatif interpersonal menurut BS EN ISO / IEC 17043: 2010 - Penilaian kesesuaian - Persyaratan umum untuk pengujian kecakapan. Dua parameter z-score dan z-robust digunakan sebagai kriteria untuk penilaian evaluasi metode. Hasil menunjukkan bahwa baik z-score dan z-robust memberikan hasil yang sama pada kinerja yang memuaskan untuk aspek inputpanas, sedangkan kinerja yang berbeda dihasilkan dari aspek efisiensi. Z-score dari aspek efisiensi memberikan kinerja yang memuaskan, sedangkan kinerja yang dipertanyakan dihasilkan oleh z -robust. Analisis lebih lanjut dari z-robust me mu nculkan perhatian tentang hubungan yang tidak konsisten dari hasil antara kenaikan suhu, konsumsi gas, dan durasi pengujian. Kurangnya metode untuk memastikan komposisi gas selama pengujian dalam SNI diidentifikasi sebagai faktor yang dapatmenyebabkan hasil yang tidak konsisten tersebut.
\end{abstract}

Kata kunci: asupan panas, efisiensi, kinerja, pengujian energi, komporgas satu tungku

\section{INTRODUCTION}

The government of Indonesia has implemented the energy policy in order to reduce the petroleum subsidy in the household sector through national program conversion kerosene to LPG since 2007. The policy was launched through Government Policy No 104, 2007. One of the factors that play an essential role in the program is the development of a national standard (SNI) 7368:2007 for gas stove packages. This standard constitutes of quality compliance, a method for testing related safety and performance of gas stove (Budya and Arofat, 2011).

During eleven years of implementation, the SNI has been amended two times in which the 
last version is SNI 7368:2011. In both version, 2007 and 2011, there are no substantive amendments both for quality compliance requirement and the test method of heat input and efficiency (SNI 7368:2007, 2006; SNI $7368: 2011,2011)$. One of the performance aspects of a gas stove that should be determined is heat input and energy efficiency. Both aspects are very crucial to be determined as it will be a basis for the impact of the energy conversion program such as emission reduction, energy saving and economic benefit. With regard to this importance, the accurate method for such energy performance aspects is necessary to be established. Therefore, this paper aims to evaluate heat input and efficiency test method of SNI 7368:2011 - kompor gas bahan bakar LPG satu tungku dengan sistem pemantik. The evaluation is carried out through interpersonal comparative test according to BS EN ISO/IEC 17043:2010 - Conformity assessment - General requirements for proficiency testing. Two parameters of z-score and z-robust are used as criteria for the assessment of method evaluation. Finally, this study may offer a basis of accurate assessment of national energy conversion impact as an accurate method will provide an actual result of performance. Furthermore, it will offer a technical foundation for energy efficiency standardization of LPG gas stove.

\section{BASIC THEORY}

Several studies have been conducted to evaluate the heat input and efficiency for LPG gas stove based on the SNI 7369:2011. A study conducted by Kusnandar evaluated LPG consumption during the efficiency test in order to eliminate the heat input test (Kusnandar and Utomo, 2016). However, this study failed to mention whether or not the data collected by different people. This unclear methodology could lead to the bias of data collected during the test. Another study of gas stove performance was conducted to examine input pressure during the period of test to the heat input value of double burners gas stove (Kusnandar, 2015). This study did not specify the burner characteristic such as the material of burner, the diameter of the burner, and the number of the hole on the burner used in the experiment. It is essential to specify the burner characteristic since this could influence the performance of a gas stove.

Khan and Saxena conducted a study of the effect of burner characteristic to the performance of the gas stove. Both studies used a similar method and formula as in SNI 7368:2011 to evaluate thermal performance. The crucial point of this method compared to the method in SNI $7368: 2011$ is that the determination of gas consumption in both studies was carried by weighing the LPG gas cylinder on the digital weighing mass during the test. They also used a stirrer to stirring the water inside the vessel in order to make sure the uniformity of heat distribution during the test (Khan, Saxena and Singh, 2012; Khan and Saxena, 2013). Another study conducted by Pantagi et al. used a similar formula as in SNI 7368:2011 to determine the LPG cooking stove due to porous media applied on the burner head (Pantangi, Kumar, Mishra, and Sahoo, 2007).

Meanwhile, Aisyah et al. applied the energy method in SNI 7368:2007 to examine the effect of preheating on the efficiency of LPG-fuelled small industrial burner (Aisyah, Rulianto and Wibowo, 2015). An experimental study conducted by Boggavarapu et al. used Indian standard (IS) 4246:2002 which has a similar method and formulation for evaluation of thermal efficiency of LPG and PNG-fired burners (Boggavarapu, Ray and Ravikrishna (2014). 2014). The same method and formulation were applied in studies carried out by Ko and Lin, Hou et al., and Wong et al. in order to assess the thermal efficiency of the gas burner. However, there is a different method for temperature rise determination of the water inside the vessel to the method in SNI 7369:2011. In this case, the water was heated through a $50{ }^{\circ} \mathrm{C}$ temperature rise (from $30^{\circ} \mathrm{C}$ to $80^{\circ} \mathrm{C}$ ) (Ko and Lin, 2003; Hou, Lee and Lin, 2007; Li, Wong, Leung and Probert, 2006).

From the studies mentioned above, it can be concluded that the temperature rises of the water inside the vessel, the gas consumption during the test and the mass of water are crucial components in the efficiency determination. These components may lead to different performance resulted by the gas stove.

However, there is little attention that has been paid to evaluate the test method of performance of the gas stove. It is important to evaluate this method as it will contribute to the standardization improvement. The current study is conducted to evaluate the energy performance test of a single gas stove in SNI 7368:2011, which consisting of heat input and efficiency. As performance is related to energy, the evaluation should meet the requirement of energy testing. According to Meier and Hill, the energy test procedure should represent the actual condition of usage and easy to be modified in order to accommodate technological development (Meier and Hill, 1998).

With regard to the test result, the energy testing should provide accurate and repeatable results, and the results can be easily compared with results from another test procedure. Furthermore, the method should cover a wide range of model within categories of appliances (Meier and Hill, 1998). 
(Bayu Utomo, Nanang Kusnandar, Qudsiyyatul Lailiyah, and Winda Sari Ramadhani)

\section{METHODS}

\section{a. Material}

A single burner gas stove was selected in this study. It has 42 holes on its burner and the burner is made from alumunium base.

The method for heat input and efficiency of LPG single burner gas stove was determined according to SNI 7368: 2011. A commercial LPG was used as a fuel in this measurement. An analogue pressure gauge was used to measure the pressure of LPG which has the measurement range from $0-1000 \mathrm{mmH} 2 \mathrm{O}$ and resolution of 20 $\mathrm{mmH2O}$. A commercial gas regulator was used on the LPG gas tube to make sure the input pressure of LPG in the range of working pressure required in SNI 7368:2011.

In the efficiency determination, the measurement of mass in water was carried out using a digital mass scale. It has the resolution of $0,5 \mathrm{~g}$, and the maximum mass that can be weighed is $15 \mathrm{~kg}$. The vessel and vessel lid used in the mass of water determination has a thickness of $0,5 \mathrm{~mm} \pm 0,1 \mathrm{~mm}$ (SNI 7368:2011, 2011). Meanwhile, the dimension of the vessel used to determine the efficiency depends on its heat input value as shown in Table 1. One of the crucial steps in efficiency determination is the measurement of the temperature of the water inside the vessel. In this case, a wire thermocouples type $\mathrm{K}$ with a diameter of $0,3 \mathrm{~mm}$ was used. The wire thermocouples were prepared in compliance with procedure for preparation, attachment, extension and use of thermocouples (CTL-OP 108-Ed 1, 2004).

Table 1 The heat input corresponds to the diameter of vessel and mass of water (SNI 7368:2011, 2011).

\begin{tabular}{cccc}
\hline $\begin{array}{c}\text { Heat Input } \\
(\mathbf{k W})\end{array}$ & $\begin{array}{c}\text { Diameter } \\
\text { of Vessel } \\
(\mathbf{m m})\end{array}$ & $\begin{array}{c}\text { Height } \\
\text { of } \\
\text { Vessel } \\
(\mathbf{m m})\end{array}$ & $\begin{array}{c}\text { Minimum } \\
\text { Water } \\
\text { Mass } \\
(\mathbf{k g})\end{array}$ \\
\hline $1,16 \sim 1,64$ & 220 & 140 & 3,7 \\
$1,65 \sim 1,98$ & 240 & 150 & 4,8 \\
$1,99 \sim 4,20$ & 260 & 160 & 6,1 \\
\hline
\end{tabular}
of instruments used in this study is from calibration certificate of digital mass scale, analouge pressure gauge, and digital timer. Therefore, the data analyzed in this study were based on the data collected from the measurement and correction given by the calibration certificate of the measuring instrument.

\section{b. Method}

Following the guidelines of SNI 7368: 2011, the heat input was estimated by determining LPG consumption for one hour. The method of determination of LPG consumption was carried out by measuring the initial and final mass of LPG through the weighing method. Finally, the heat input was calculated based on the following formula:

$$
Q_{n}=\frac{1000 \times M_{n} \times H_{s}}{3600}
$$

Where:

$\begin{array}{ll}\text { Qn }(\mathrm{kW}) & =\text { the heat input } \\ 1000 & =\text { factor } \\ \mathrm{Mn}(\mathrm{kg} / \mathrm{hour} & =\text { the mass flow rate } \\ \mathrm{Hs}(49,14 & =\text { the caloric value of gas } \\ \mathrm{MJ} / \mathrm{kg}) & \end{array}$

The procedure for efficiency according to SNI 7368:2011 of gas stoves was started by heating the $3,7 \mathrm{~kg}$ of water for 10 minutes in the vessel with $200 \mathrm{~mm}$ in diameter. The input pressure of LPG was maintained at $280 \mathrm{mmH}_{2} \mathrm{O}$ $\pm 5 \mathrm{mmH}_{2} \mathrm{O}$. An analogue pressure gauge was used in order to make sure that pressure gas inlet in the range of requirement.

The determination of efficiency was carried out by boiling the water inside the vessel. For this purpose, the mass of water inside the vessel was specified under the heat input generated by a gas stove. Table 1 shows the dimension of the vessel used, and minimum water mass for efficiency determination in relation to the heat input produced by the gas stove. Prior to boiling the water, it is important to make sure that the temperature of the water inside the vessel in the range of $20^{\circ} \mathrm{C} \pm 0,5^{\circ} \mathrm{C}$. A wire thermocouple located in the middle of the volume of water was used in this purpose which was connected with the data logger system and computer in order to collect the temperature of the water inside the vessel. The gas stove was turned off immediately when the temperature of the water inside the vessel reached $90^{\circ} \mathrm{C} \pm 1^{\circ} \mathrm{C}$. The efficiency value was calculated by obtaining the maximum temperature of the water inside the vessel after gas stove had been turned off. In this case, the maximum temperature of the water was acquired 10 seconds after the gas stove had turned off.

Meanwhile, the consumption of LPG gas was obtained by determining the initial and final mass of LPG. A similar weighing method with heat input determination was applied in this case. Finally, the efficiency of the gas stove was calculated using Eq. 2 as follows. 


$$
\eta=\frac{4.186 \times 10^{-3} \times\left(t_{2}-t_{1}\right)}{\left(M_{C} \times H_{S}\right)} \times 100 \%
$$

Where:

$$
\begin{array}{lll}
\eta(\%) & = & \text { efficiency } \\
\mathrm{Me}(\mathrm{kg}) & = & \text { total amount of water mass } \\
& \text { and vessel and lid vessel, } \\
\mathrm{t} 1 & = & \text { initial water temperature } \\
\mathrm{t} 2 & & \text { maximum of water } \\
& \text { temperature } \\
\mathrm{Mc}(\mathrm{kg}) & \text { mass of gas consumption } \\
\mathrm{H}_{\mathrm{s}}(49,14 \mathrm{MJ} / \mathrm{kg}) & = & \text { the caloric value of gas }
\end{array}
$$

The evaluation of the test method of heat input and efficiency was carried out according to the principles on BS EN ISO IEC 17043:2010 for conformity assessment of proficiency testing. The justification was made based on the purposes of the standard. One of the purposes of the standard that could be relevant to the current study is that the aim of the standard is to evaluate the performance of laboratories for specific tests of measurements and monitoring laboratories' continuing performance. In this case, the specific test was made for heat input and efficiency for LPG single gas stove. With regard to the aim of the current study, although the proficiency testing does not usually address the evaluation of the performance characteristics of the method, the application of the standard could be performed to provide independent demonstrations of laboratory competence. Furthermore, the requirements of the standard can be applied to technical planning and operational activities in the area of evaluation of the performance characteristic of the method. According to this guidance, the methods for evaluation was performed in the following steps, i.e. determination of the assigned value, calculation of performance statistics, and evaluation of performance (BS EN ISO/IEC 17043:2010, 2010; ISO 13528:2005, 2005). In the current study, the evaluation was performed by interpersonal comparative tests involving five participants with capability to perform gas stove test based on SNI 7368:2011.

\section{RESULTS AND DISCUSSIONS}

a. Overview of test method for LPG single gas stove

The national standard of a single gas stove for LPG has two versions since launched in 2007. The first version of SNI 7368:2007 has been amended by SNI 7368:2011. They are several amendments have been made for both quality compliance and test method. According to this revision, seven test methods has been amended out of ten methods should be performed for quality compliance assessment. With regard to the heat input and efficiency test method, the substantial amendment has been made to the pressure inlet of LPG to the gas stove. In this part, the tolerance of input pressure of $5 \mathrm{mmH}_{2} \mathrm{O}$ has been added in the new version. Table 2 illustrates the amendment for the test method of SNI for a single gas stove for LPG.

In this current study, the determination of heat input and efficiency was performed according to the SNI 7368:2011 and therefore, the input pressure of LPG was maintained at the range of requirement.

Table 2 Test method gap of SNI for single gas stove LPG

Test Method SNI 7368:2007
The gas pressure for the test is not stated

- Efficiency measurement is carried out with a gas pressure input of $280 \mathrm{mmH}_{2} \mathrm{O}$.

Flame Test

- The height of $200 \mathbf{~ m m}$ diameter of the vessel for preheating is stated in Table 2 in the standard
The test carried out at the gas pressure of $\mathbf{2 8 0}$ $\mathrm{mmH}_{2} \mathrm{O} \pm 5 \mathrm{mmH}_{2} \mathrm{O}$

- Efficiency measurement is carried out with a gas pressure input of $280 \mathrm{mmH}_{2} \mathrm{O} \pm 5$ $\mathrm{mmH}_{2} \mathrm{O}$.

- The height of $\mathbf{2 0 0} \mathbf{~ m m}$ diameter of the vessel for preheating is not stated in Table 2

The colour of the top of flame should not turn The colour of the flame core should not turn to to the yellow-reddish the yellow-reddish

The gas pressure for the test is not stated The test carried out at the gas pressure of $\mathbf{2 8 0}$ $\mathrm{mmH}_{2} \mathrm{O} \pm 5 \mathrm{mmH}_{2} \mathrm{O}$

Temperature Rise The measured area is outside the area covered The measured area is specified around the by vessel projection. Not conducted knob and front of the body of stove. There is a measurement of heat propagation in the gas stove pipe

\begin{tabular}{lll}
\hline Stability Test & $\begin{array}{l}\text { The test is carried out with a vessel of } \emptyset \mathbf{2 0 0} \\
\mathbf{m m} \text { and } \mathbf{1 3 0} \mathbf{~ m m} \text { in height. }\end{array}$ & $\begin{array}{l}\text { The dimension of the vessel is } \emptyset \mathbf{2 2 0} \mathrm{mm} \text { and } \\
\mathbf{1 4 0} \mathbf{~ m m} \text { in height }\end{array}$ \\
\hline \multirow{3}{*}{ Strength Test } & Not conducted & There is a grid layer strength test \\
& Not conducted & $\begin{array}{l}\text { There is a strength test for glass or ceramic } \\
\text { material }\end{array}$
\end{tabular}


An Evaluation of Heat Input and Efficiency Test Method Based on SNI 7368:2011 - Single Burner LPG Gas Stove With lgniter System

(Bayu Utomo, Nanang Kusnandar, Qudsiyyatul Lailiyah, and Winda Sari Ramadhani)

\begin{tabular}{|c|c|c|}
\hline Test Method & SNI 7368:2007 & SNI 7368:2011 \\
\hline & Not conducted & There is a thermal shock test \\
\hline \multirow{3}{*}{ Visual Test } & $\begin{array}{l}\text { There is no visual test carried out to the } \\
\text { installation of electrical components }\end{array}$ & $\begin{array}{l}\text { The stove is visually not dented, bouncy, the } \\
\text { flame is still blue, and the installation of } \\
\text { electrical components should be installed } \\
\text { neatly }\end{array}$ \\
\hline & $\begin{array}{l}\text { Visual test is performed for components that } \\
\text { need regular maintenance such as grid, } \\
\text { burner, burner support, or others. }\end{array}$ & $\begin{array}{l}\text { Visual test is performed for components that } \\
\text { need a regular maintenance especially grid } \\
\text { and burner. }\end{array}$ \\
\hline & $\begin{array}{l}\text { The opening knob of the gas flow should be } \\
\text { anti-clockwise. }\end{array}$ & $\begin{array}{l}\text { The opening knob of the gas flow should be } \\
\text { anti-clockwise or press the system. }\end{array}$ \\
\hline $\begin{array}{l}\text { Rust Resistance } \\
\text { Test }\end{array}$ & $\begin{array}{l}\text { The part of stove taken as the test object is not } \\
\text { specified }\end{array}$ & $\begin{array}{l}\text { The unit testis taken from the part of the stove } \\
\text { body }\end{array}$ \\
\hline $\begin{array}{l}\text { Endurance Test } \\
\text { Valve and Ignitio }\end{array}$ & Endurance test is only carried of for igniter & $\begin{array}{l}\text { Endurance test is carried of for valve and } \\
\text { igniter }\end{array}$ \\
\hline
\end{tabular}

a. Calculation of z-score and z-robust

The evaluation of test method is performed by evaluating the test result from the participating participant through determination of $z$-score and z-robust. The z-scores are calculated from participant's result, assigned value, and standard deviation. Mathematically, it can be formulated as follow (ISO 13528:2005, 2005):

$z-$ scores $=\frac{x_{i}-X}{\hat{\sigma}}$

Where:

$\mathrm{g}_{\mathrm{i}} \quad=$ participant's result

$\mathrm{X}=$ assigned value

$\hat{\sigma}=$ standard deviation

According to the BS EN ISO 17043:2010, the definition of assigned value is referred to the value attributed to a particular property of a proficiency test item (BS EN ISO/IEC 17043:2010, 2010). In this case, the assigned value is obtained from the average of all participant's result. The values of z-score for heat input and efficiency are presented in Fig. 1.

Meanwhile, the robust z-score is one of alternative method that provide the statistical influences of outlying events on a sample population. The determination of the value is based on median of the population. Mathematically, the z-robust is formulated by following equation (ISO 13528:2005, 2005):

$z-$ robust $=\frac{x_{i}-M}{r S D}$

Where:

$\mathrm{M}=$ median of participant's data

$\mathrm{S}$ and $\mathrm{rSD}=$ robust standard deviation

The calculation of robust standard deviation is based on the deviation of individual data points to the median of population. It is formulated as (ISO 13528:2005, 2005):

$r S D=\left(\right.$ medianof $\left\{x_{i}-\right.$ median $\left.\left._{x}\right\}\right) \times 1,4826$

where the value 1,4826 is constant factor that adjusts the resulting robust value to the equivalent of a normal population distribution (ISO 13528:2005, 2005). The values of $z$ robust for heat input and efficiency are presented in Fig. 2.

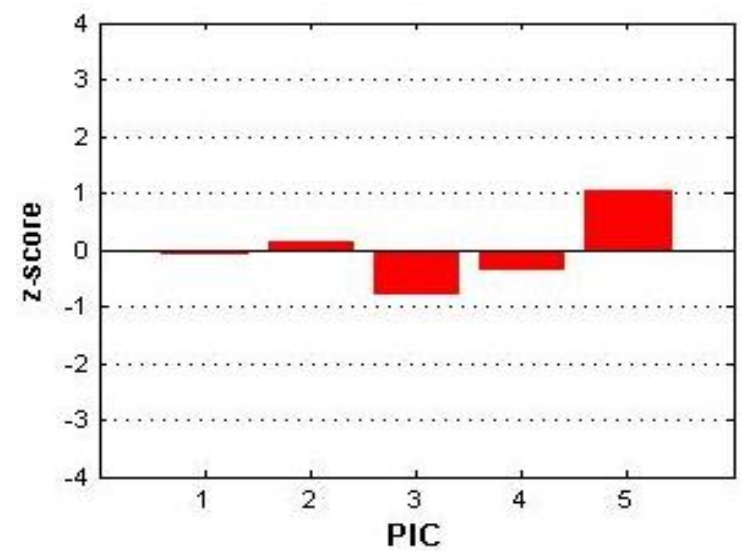

(a)

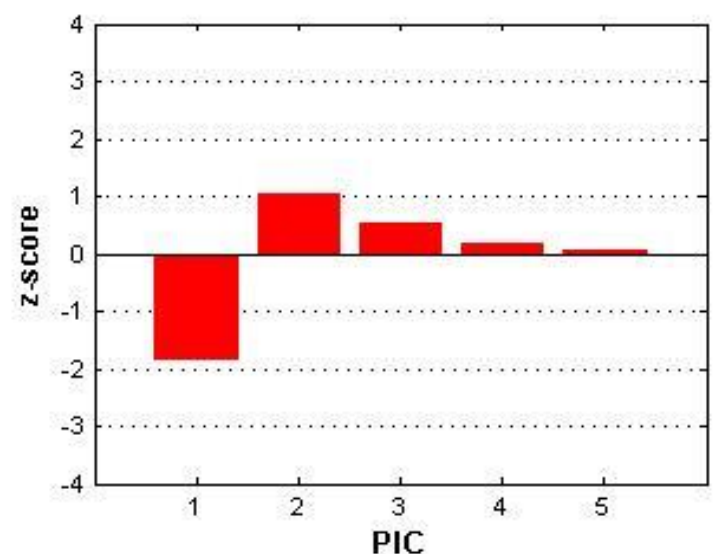

(b)

Figure 1 Values of z-score, (a) heat input, (b) efficiency. 


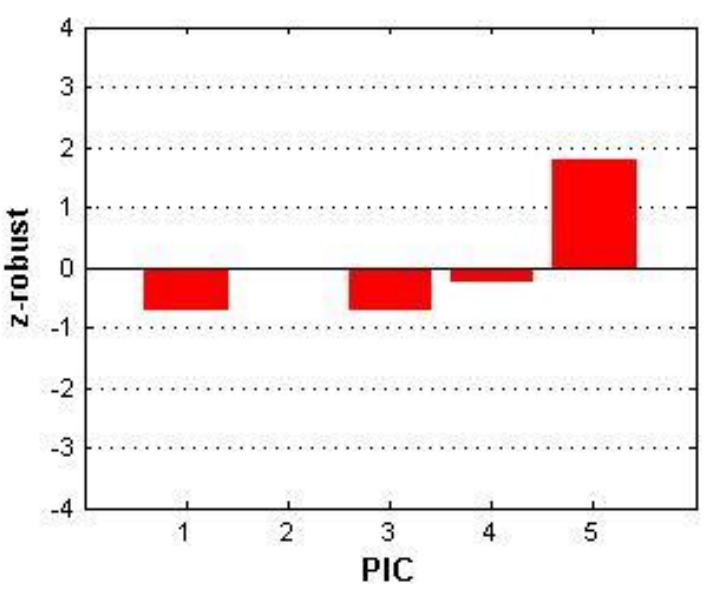

(a)

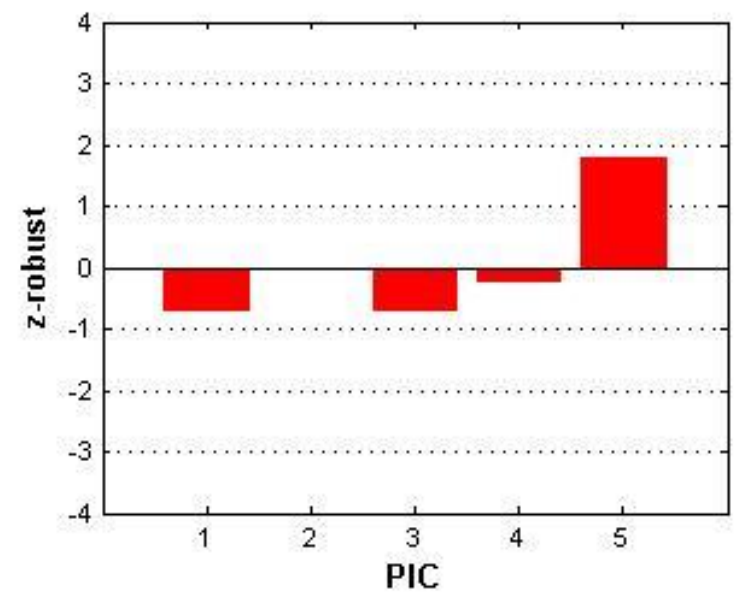

(b)

Figure 2 Values of z-robust, (a) heat input, (b) efficiency.

\section{b. Evaluation of performance}

The evaluation of test method is carried out by determining the category of performance based on z-score and z-robust above. According to BS EN ISO/IEC 17043:2010, the laboratory with satisfactory performance has $|z| \leq 2$, the questionable performance $2<|z| \leq$ 3 , and $|z| \geq 3$ means that the laboratory indicates an unsatisfactory performance (BS EN ISO/IEC 17043:2010, 2010).

According to Fig. 1(a) and Fig. 2(a), all of participated participant indicates a satisfactory performance on heat input test. The z-score and z-robust values shows a similar result regarding the consistency of heat input results with exception participant 5 in which the z-robust is quite high, reach to 1,78 . This is due to the median of heat input from participant 5 is higher than that of the other participants. The determination of $z$-robust itself is based on median and robust standard deviation. Table 3 represents the results of the heat input data.

Table 3 Heat input data.

\begin{tabular}{cccccc}
\hline $\begin{array}{c}\text { Read } \\
\text { no. }\end{array}$ & PIC 1 & PIC 2 & PIC 3 & PIC 4 & PIC 5 \\
\hline 1 & 1,86 & 1,88 & 1,86 & 1,88 & 1,91 \\
2 & 1,81 & 1,88 & 1,78 & 1,88 & 1,89 \\
3 & 1,85 & 1,89 & 1,91 & 1,82 & 1,95 \\
4 & 1,89 & 1,89 & 1,89 & 1,90 & 1,95 \\
5 & 1,98 & 1,91 & 1,77 & 1,85 & 1,97 \\
\hline Mean & 1,88 & 1,89 & 1,84 & 1,87 & 1,93 \\
Median & 1,86 & 1,89 & 1,86 & 1,88 & 1,95 \\
\hline
\end{tabular}

The different result occurred for efficiency criteria. The z-score and z-robust for participant 1 indicate significantly different values as presented by Fig. 1(b) and Fig. 2(b). The z-score for participant 1 is in satisfactory performance, while the z-robust is $-2,85$, which means that the participant 1 has questionable performance. The difference between both values may be due to the fact that the determination takes in a different approach, which can be understood from Eq. 3 and Eq. 4. According to Eq. 3, the assigned value and standard deviation for z-score are determined from the average value of the test result, which means that the outlier numbers could influence the determination.

Table 4 Efficiency data

\begin{tabular}{cccccc}
\hline $\begin{array}{c}\text { Read } \\
\text { no. }\end{array}$ & PIC 1 & PIC 2 & PIC 3 & PIC 4 & PIC 5 \\
\hline 1 & 51,91 & 67,55 & 64,40 & 65,70 & 62,18 \\
2 & 54,55 & 67,95 & 64,26 & 61,31 & 62,56 \\
3 & 52,32 & 66,65 & 64,04 & 62,45 & 62,02 \\
4 & 52,68 & 66,65 & 64,36 & 60,45 & 62,05 \\
5 & 52,77 & 67,08 & 66,36 & 64,23 & 62,87 \\
\hline Mean & 52,84 & 67,18 & 64,68 & 62,83 & 62,34 \\
Median & 52,68 & 67,08 & 64,36 & 62,45 & 62,18 \\
\hline
\end{tabular}

Table 4 shows the test result of efficiency from five participants. According to Table 4, the average value of efficiency resulted in participant 1 is around $18 \%$ lower than that of efficiency resulted from the other four participants. Although the gap of participant 1 is quite high relative to the other four participants, there is no suspected outlier, as indicated in Fig. 3. The suspected outlier of data can be determined through limit outliner from boxplot of efficiency, as presented in Fig. 3. According to Fig. 3, it is clear that the efficiency data has $57,59 \%$ for quartile 1 (Q1), $62,83 \%$ for Q2, and 63,93\% for Q3. From these quartiles, the limit for minor outliner is 
obtained at $48,08 \%$ and $54,42 \%$ and extreme outliner at $44,91 \%$ and $82,95 \%$ (Mattjik and Sumertajaya, 2013). Therefore, it can be said that the bias of data analysis due to outlier can

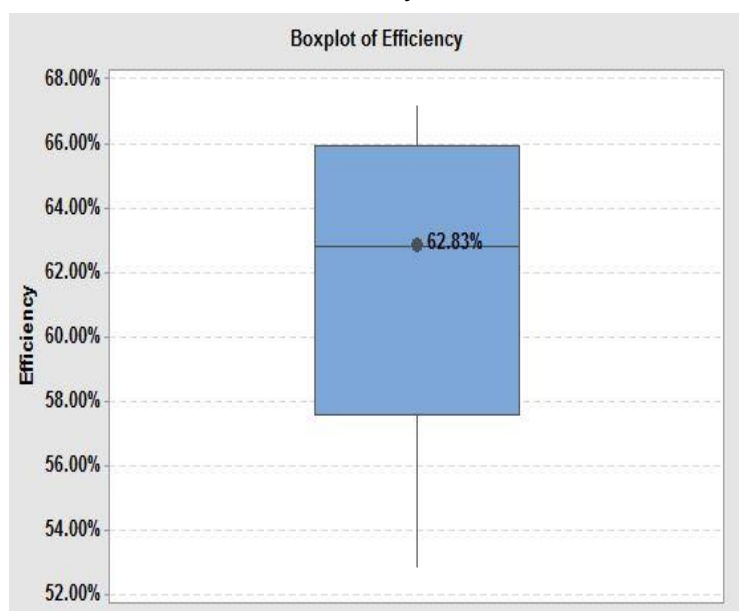

be avoided as there is no single efficiency result presented in Table 4 in the range of outlier limit.

Figure 3 Boxplot of efficiency.

In contrast, the basis of z-robust determination is derived from the median, as stated in Eq. 4 and Eq. 5. As the basis determination takes the middle value of the sorted results, the influence of outlier results is minimal; in some cases, it could be avoided (Hegazy, Mohamed and Abu-Sinna, 2010). Interestingly, although the gap of the median from participant 1 to the other four participants has the same value with the gap due to the average value, the different performance criteria are resulted by participant 1 . The components of the efficiency formula may be indicated as factors that lead to such different criteria. According to the formula for heat input calculation governed by Eq. 1 and efficiency from Eq. 2, the efficiency calculation has more components relative to heat input. These components include the temperature rise of water and the mass of water inside the vessel.

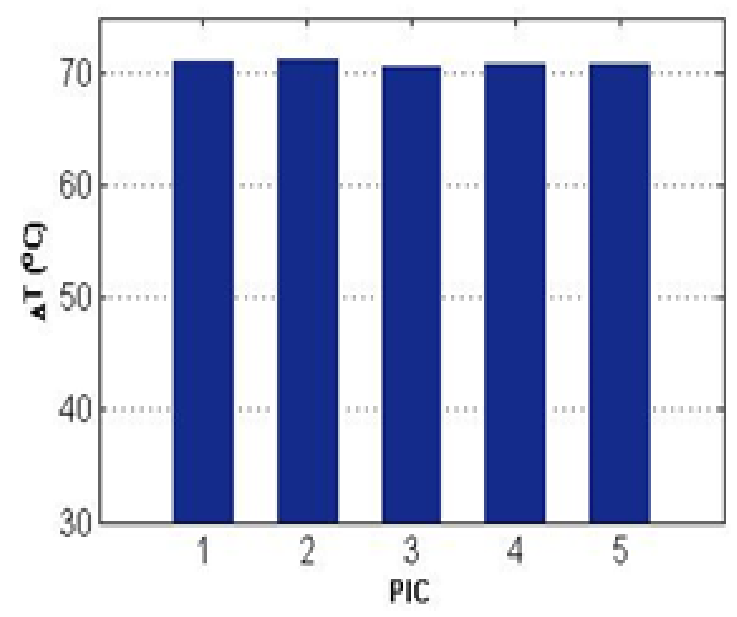

Figure 4 The temperature rises during the test of participants.

Fig. 4 and Fig. 5(a), and 5(b) show the temperature rise of water inside the vessel, gas consumption, and duration of test for each participant, respectively. According to Fig. 4, all of the participants have a similar temperature rise, around $71^{\circ} \mathrm{C}$. This value is obtained from the initial temperature and maximum temperature of the water inside the vessel. The significant gap is found in the duration of the test between participant 1 and other participants. Fig. 5 (a) shows that the average duration test of participant 1 takes 4 minutes longer than that of other participants (2 until 5), around 26 minutes participant 1 and around 22 minutes for other participants. This gap brings to the consequence that the gas consumption during the test for participant 1 is greater than that of the other participants as figured in Fig. 5(b). Although the initial volume of LPG used for the efficiency test for participants has a similar volume, an average of gas consumption at $0,06 \mathrm{~kg}$ is needed for participant 1 for performing efficiency test compared with around 0,05 $\mathrm{kg}$ gas consumption for the other participants as presented in Fig. 5(b). Table 5 confirms that the initial mass of LPG used in the efficiency

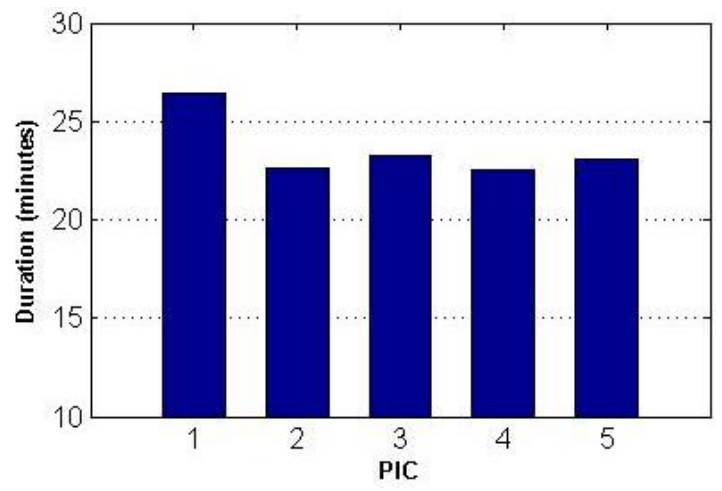

test.

(a)

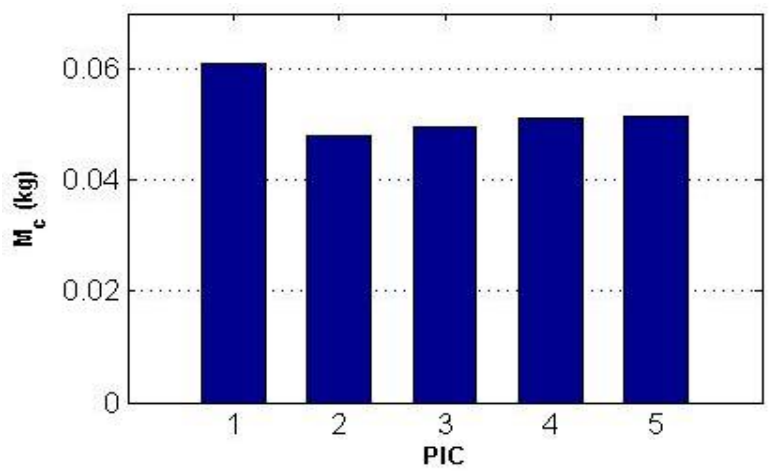

(b) 
Figure 5 (a) The test duration of all participants, (b) the gas consumption during the efficiency test of all participants.

Table 5 The initial mass of gas used for efficiency test.

\begin{tabular}{cccccc}
\hline & \multicolumn{5}{c}{ Initial Mass of Gas (kg) } \\
$\begin{array}{c}\text { Read } \\
\text { no. }\end{array}$ & PIC 1 & PIC 2 & PIC 3 & PIC 4 & PIC 5 \\
\hline 1 & 7,056 & 7,384 & 7,672 & 6,521 & 6,340 \\
2 & 6,985 & 7,335 & 7,616 & 6,691 & 6,288 \\
3 & 6,896 & 7,287 & 7,561 & 6,638 & 6,237 \\
4 & 6,828 & 7,192 & 7,495 & 5,676 & 6,185 \\
5 & 6,756 & 7,143 & 7,432 & 6,472 & 7,965 \\
\hline Mean & 6,904 & 7,268 & 7,555 & 6,400 & 6,603 \\
\hline
\end{tabular}

In relation to the limit of minor and extreme outlier presented in Table 6, the data show that there is no suspected outlier although the test duration and the gas consumption of participant 1 during the efficiency test has a significant gap relative to the other four participants. Table 6 presents the limit of a minor and extreme outlier for temperature rise, gas consumption, and duration during the efficiency test.

Table 6 Quartiles and limit outlier of temperature rise, gas consumption, and duration of test during the efficiency test.

\begin{tabular}{lrrr}
\hline Component & $\boldsymbol{\Delta} \mathbf{T}\left({ }^{\circ} \mathbf{C}\right)$ & $\mathbf{M c}(\mathbf{k g})$ & Duration \\
\hline Q1 & 70,5 & 0,0492 & $0: 22: 41$ \\
Q2 & 71,31 & 0,0509 & $0: 22: 59$ \\
Q3 & 71,55 & 0,0527 & $0: 23: 40$ \\
\hline \multirow{2}{*}{ Minor outlier } & 68,92 & 0,0440 & $0: 21: 12$ \\
& 73,12 & 0,0579 & $0: 25: 09$ \\
\hline \multirow{2}{*}{ Extreme } & 68,4 & 0,0422 & $0: 20: 43$ \\
outlier & 74,7 & 0,0632 & $0: 26: 37$ \\
\hline
\end{tabular}

The inconsistency results between data in Fig.4 and Fig.5(a) and Fig.5(b) in relation to Table 5 may occur since there is no method to measure the composition of gas used during the test. Table 2 confirms that the method for the flame test, including efficiency and heat input test, does not specify the quality of LPG required for the test and there is no method to measure the composition of gas used during the test. It is essential to perform the mechanism to oversee the composition of LPG during the test as it could lead to the bias of measurement results. Generally, the composition of LPG consists of propane $\left(\mathrm{C}_{3} \mathrm{H}_{8}\right)$, propylene $\left(\mathrm{C}_{3} \mathrm{H}_{6}\right)$, butane $\left(\mathrm{C}_{4} \mathrm{H}_{10}\right)$, butylene $\left(\mathrm{C}_{4} \mathrm{H}_{8}\right)$ and the small part of ethane $\left(\mathrm{C}_{2} \mathrm{H}_{4}\right)$ and pentane $(\mathrm{C} 5 \mathrm{H} 12)$. Furthermore, the existing LPG products have different purposes according to the compositions of the LPG product. In term of cooking purposes, the types of LPG that mainly used are LPG butane and mixed LPG (Syukur, 2009). There is another concern to measure the initial temperature of the gas as it influences efficiency (Aisyah et al., 2015). The importance of measuring the composition of LPG during the test is that it will determine the caloric value of gas, which is one of the essential components for efficiency determination. In the current study, a commercial LPG used for the test and there is no procedure to make sure the composition of LPG during the test.

\section{CONCLUSION}

The evaluation of heat input and efficiency test method for a single gas stove has been performed in this study. The different approach of z-score and z-robust based on conformity assessment for proficiency testing was applied as a method for evaluation. The evaluation shows that both z-score and z-robust for heat input test method produce the same result at satisfactory performance criteria, while for efficiency method, the values give the different result at a satisfactory performance by z-score and questionable performance criteria by $z$ robust. This different result may be due to the fact the difference of basis for determination between z-score and z-robust. Although, the evaluation of $z$-robust of efficiency results in questionable criteria, the efficiency data shows that there is no suspected outlier data fo efficiency. Therefore, it could be said that the $z$-score is better to be used for the evaluation.

Although the z-robust could be avoided in the evaluation criteria, the method could be applied as an alternative approach in order to determine how far the components of test method affecting the reliability of the test method. In this current study, further analysis of z-robust brings to the concern of components involved in efficiency determination. An inconsistent result between temperature rise and gas consumption of gas during the test, together with the duration of the test emerges in the participant 1 relative to the other four participants. The absence of a method to ensure the composition and temperature of LPG used during the test may be identified as the factor that lead to such an inconsistent result. Therefore, it could be inferred that the method for ensuring the gas composition and temperature of LPG during the test could be considered as critical factors for ensuring the reliability of performance test method. 


\section{ACKNOWLEDGMENT}

The authors would like to take this opportunity to thank Mr. Heri Mulyana as Technician of Electrical, Energy, and Environmental Laboratory for his support in the measurement.

\section{REFERENCES}

Aisyah, L., Rulianto, D., and Wibowo, C.S. (2015). Analysis of the effect of preheating system to improve efficiency in LPG-fuelled small industrial burner. Energy Procedia, 65, 180-185), $\left[3^{\text {rd }}\right.$ Conference and Exhibition Indonesia - New and Renewable Energy and Energy Conservation]

Boggavarapu, P., Ray, B., and Ravikrishna, R.V. (2014). Thermal efficiency of LPG and PNG-fired burners: experimental and numerical studies. Fuel, 116, 709715

BS EN ISO/IEC 17043:2010. (2010). Conformity assessment - General requirements for proficiency testing (ISO/CASCO 17043:2010). The United Kingdom.

Budya, H., and Arofat, M.Y. (2011). Providing cleaner energy access in Indonesia through the megaproject of kerosene conversion to LPG. Energy Policy, 39, 7575-7586.

CTL - OP 108 Ed. 1. (2004). Laboratory procedure for preparation, attachment, extension and use of thermocouples. Denmark.

Hegazy, R., Mohamed, M.I., and Abu-Sinna. A. (2010). A comparative study of statistical methods used in analyzing the proficiency testing results of yield stress. Journal of Metrology Society of India, vol. 25, no. 2, 107-113.

Hou, S.S., Lee, C.Y., and Lin, T.H. (2007). Efficiency and emissions of a new domestic gas burner with a swirling flame. Energy Conversion and Management, 48, 1401-1410.

ISO 13528:2005 (E). (2005). Statistical methods for use in proficiency testing by interlaboratory comparisons.

Switzerland.

Khan, M.Y. and Saxena, A. (2013). Performance of LPG cooking stove using different design of burner heads. International Journal of Engineering Research and Technology, vol. 2, issue 7, 656-659

Khan, M.Y., Saxena, A. and Singh, K.P. (2012). Performance of insulated LPG burner with ball bearings as porous medium. People's Journal of Science and Technology, vol. 2(1).

Ko, Y.C. and Lin, T.H. (2003). Emissions and efficiency of a domestic gas stove burning natural gases with various compositions. Energy Conversion and Management, 44, 3001-3014

Kusnandar, K., and Utomo, B. (2016). Penggunaan data massa LPG terpakai selama uji efisiensi untuk perhitungan nilai asupan panas kompor gas. Prosiding Annual Meeting and Testing, 305-311.

Kusnandar, N. (2015). Metode pengukuran asupan panas kompor gas berdasarkan SNI 7638:2011 dan SNI 7469:2013. Jurnal Standarisasi, vol. 17, no. 3, 233240.

Li, H.B., Wong, T.T., Leung, C.W., and Probert, S.D. (2006). Thermal performances and $\mathrm{CO}$ emissions of gasfired cooker-top burners. Applied Energy, 83, 1326-1338.

Mattjik, A.A., and Sumertajaya, I.M. (2013). Perancangan percobaan dengan aplikasi SAS dan Minitab. Bogor: IPB Press.

Meier, A.K. and Hill, J.E. (1998). Energy test procedures for appliances. Energy and Building, 26, 23-33.

PAN (2007). Performance analysis of domestic Ipg cooking stoves with porous media. International Energy Journal, 8, 139-144

SNI 7368:2007. (2006). Kompor gas bahan bakar LPG satu tungku dengan sistem pemantik mekanik. Jakarta, Indonesia.

SNI 7368:2007. (2011). Kompor gas bahanbakar LPG satu tungku dengan sistem pemantik mekanik. Jakarta, Indonesia.

Syukur, M.H. (2009). Penggunaan liqufied petroleum gases (LPG): Upaya mengurangi kecelakaan akibat LPG. Jurnal Forum Teknologi, vol. 01, no. 2. 
